\title{
Question of a September 1936 Plenum of the CPSU Central Committee
}

\begin{abstract}
EdITORIAL NOTE.-Upon receipt of Mr. Avtorkhanow's answer to his critics, it was sent to the persons concerned for their responses. On reviewing the exchange it was felt that the discussion, partly because of the range of issues touched on, exceeded the space at our disposal. Hence, it was requested of the participants that the exchange be limited to the specific question which had occasioned it. We regret the consequent delay in publication that has resulted.
\end{abstract}

\section{A Few Questions concerning the "Great Purge" (An Answer to My Critics)}

\section{ABDURAKHMAN AVTORKHANOV}

SLAvic Review (June 1966, pp. 353-55) contained a review by Professor Robert M. Slusser of the book The Great Purge Trial, edited, with notes, by Robert C. Tucker and Stephen F. Cohen. The review impugns the credibility of portions of my book, Staline au Pouvoir (published in English as The Reign of Stalin). ${ }^{1}$ Slusser has written:

Mr. Tucker has followed the émigré author Abdurakhman Avtorkhanov for the statement that a plenum of the Central Committee took place in September 1936, that at it a clash occurred between Stalin and his opponents, and that as a result Bukharin and Rykov won a temporary reprieve. He writes (page $\mathrm{xx}$ ): "Most Western specialists accept this account as on the whole trustworthy." On the contrary, John Armstrong, whose study of the history of the purge years is the most detailed and reliable we have, writes, "If we accept as valid Khrushchev's remarks in his secret speech to the Twentieth Party Congress, this version is scarcely tenable," 2 and elsewhere, regarding Avtorkhanov's account of events, "considerable portions have turned out to be unreliable." 3 By accepting the unsubstantiated September $193^{6}$ plenum, Mr. Tucker has lost sight of the problem of identifying the individual or individuals who defied Stalin by exonerating Bukharin, Rykov, and Tomsky and of analyzing the part they played in the drama [p. 355].

Mr. Slusser's weakness is the fact that his chief authority, Mr. Armstrong, in criticizing me, makes several fundamental mistakes. On these mistakes Mr. Slusser builds his argument. And with such an argument he wants to refute not only an "émigré author" but in fact "most Western specialists," who accept my presentation of the issue at hand. Among the specialists who have either quoted from Staline au Pouvoir or included it in their bibliographies are David Dallin, Boris Souvarine, Milovan Djilas, Boris Nicolaevsky, Leonard Schapiro, Hugh Seton-Watson, Georg von Rauch, and Zbigniew Brzezinski. In defending my book, however, I do not in-

${ }^{1}$ Staline au Pouvoir (under my pen name, Alexandre Ouralov), Paris: Les Iles d'Or (Diffusion Plon), 1951; The Reign of Stalin, London: The Bodley Head, 1953 (under the name Alexander Uralov).

${ }^{2}$ [The Politics of Totalitarianism: The Communist Party of the Soviet Union from 1934 to the Present (New York, 1961), p. 53.-As cited in Mr. Slusser's review.]

' An Essay on Sources for the Study of the Communist Party of the Soviet Union 19341960 (Washington, 1961), p. 25.-As cited in Mr. Slusser's review.] 
tend to transfer any responsibility to others. In view of the enormous amount of literature that has appeared both in the West and in the Soviet Union as a result of the Twentieth and Twenty-second Congresses of the CPSU, I am now in a position to confirm and illustrate every page and every major fact in my book with evidence based either directly on quotations or the implication of these statements.

The only assertion in my book which I am unable to document without access to the Central Committee's archives, and with which Professors Slusser and Armstrong choose to quarrel (but which they can also not refute without access to the same inaccessible archives), is my statement concerning the September plenum. But even in this matter there is a material difference between my position and that of my critics. The fact of the matter is that I was able to base my assertion on indirect evidence, while my critics seem to base their theory on (1) Khrushchev's failure to make any comment about the September $193^{6}$ plenum and (2) their mistaken notion that it would have been more difficult for Stalin to replace Yagoda as head of the NKVD than it was for him to eliminate Bukharin.

In attempting to refute my assertion that the majority of the Central Committee were against the repression of Bukharin, and in trying to prove that Stalin was in "complete command of the situation," Mr. Armstrong writes:

Stalin's complete command of the situation is shown by the fact that he did not even need to interrupt his Caucasian vacation to secure the instantaneous fall of such a key figure as Iagoda.... All of these circumstances indicate that if there was opposition at this time to the intensified purge, it was not effective.... Even the process of taking control of the police was a gradual one, however. Iagoda was nominally made Commissar of Communications; he did not officially "retire" from active duty as Commissar of State Security until January 28, 1937, when Ezhov assumed that post."

We notice that, in citing these circumstances as evidence, Armstrong has made two basic errors. The first indicates the author's lack of understanding of the internal structure of the NKVD at that time.

A specialist can easily detect the mistake that Armstrong makes in indicating his belief that there were two NKVD posts: first, the duty as People's Commissar of Internal Affairs which Ezhov took from Yagoda in September 1936 and, second, the duty of Commissar of State Security. This second post was, according to Armstrong, held by Yagoda until January 28, 1937, at which time Ezhov "assumed this post." The solution to this puzzle is very simple: The title of Commissar of State Security does not designate a post but a rank, a title, and although Ezhov had occupied the post of Commissar of Internal Affairs since the September telegram, he was not awarded the corresponding rank until January. Although he was not serving in any NKVD position, Yagoda was never stripped of his rank as Commissar General of State Security and held this title until his death in March 1938. NKVD ranks were established by decrees of the Central Executive Committee (present-day Supreme Soviet) of the USSR on October 4 and November 24, 1935. In accordance with the new regulation during World War II the Commissar General of State Security of the USSR, who headed the NKVD, was awarded the rank of Marshal of the Soviet Union. Subordinate Commissars of State Security became Soviet army generals.

The second mistake follows from the author's lack of understanding of the internal structure of the Central Committee of the Communist Party and its responsibilities in connection with the removal and appointment of the Party's high-level cadres. Armstrong apparently believes that Yagoda was such a "key figure" that he

- The Politics of Totalitarianism, p. 53. 
was more difficult to remove from his post than was Bukharin. In fact, in order to remove Yagoda as chief of the NKVD, no decision by a plenum of the Central Committee or even by the Politburo was necessary. All that was necessary was a decree by the majority of the Orgburo (now Secretariat) and after that an act by the government. Therefore, Stalin's telegram which triggered the ouster was addressed to the second secretary of the Central Committee and the chairman of the Orgburo of the Central Committee, Kaganovich, and the Chairman of the Council of People's Commissars, Molotov, for execution, and to the other members of the Politburo for information only. Although it was a simple matter for Stalin to remove Yagoda as Commissar of Internal Affairs, he was unable to topple Yagoda from his position as a candidate-member of the Central Committee until his arrest after the February-March plenum of 1937 .

I would like now to review my comments concerning the September (1986) plenum. The first attempt to liquidate the Bukharin group was made by Stalin just before he engineered the Zinoviev-Kamenev trial (August 1936). In the process of this attempt Bukharin's name was first linked with Zinoviev.

At the trial of Zinoviev and Kamenev, Procurator Vyshinskii made the following statement: "At previous sessions some of the defendants (Kamenev, Zinoviev, and Reingol'd) testified that Tomskii, Bukharin, Rykov, Uglanov, Radek, Piatakov, Serebriakov, and Sokol'nikov were in various degrees involved in their criminal counterrevolutionary activity... Yesterday I directed that an investigation be started concerning these statements." ${ }^{\circ}$ Central Committee candidate-member Tomskii reacted to the publication of Vyshinskii's statement by committing suicide the same day (August 22, 1936). Stalin had his own reasoning-he considered Tomskii's suicide not an act of protest against slander but an acknowledgment of guilt. Consequently, the Central Committee's official statement on the incident read as follows: "The Central Committee of the VKP (B) reports that Central Committee candidate-member Tomskii, who had become entangled with the counterrevolutionary Trotsky-Zinoviev terrorists, has committed suicide." •

A furious press campaign was launched, demanding that the right-wingers be brought to trial. In his secret speech at the Twentieth Congress twenty years later Khrushchev, of course, carefully avoided the subject, since he had been one of Stalin's closest assistants in the liquidation of the right-wingers. In August ${ }_{1936} 6$ Khrushchev gave a report to a meeting of Moscow party functionaries. As a result of this report the following resolution was adopted: "The Moscow party organization meeting fully and completely endorses the decision to investigate the connection between Rykov, Bukharin, and Uglanov and the Trotskyites, and to investigate Radek, Piatakov, and others who are known for their Trotskyite activity." ? At the same time, without the permission of the Central Committee, and thus in violation of the party's regulations, Stalin and Ezhov created a criminal case against Bukharin and Rykov. However, since Bukharin and Rykov were candidate-members, and Piatakov even a full member, of the Central Committee, it was not possible to try them without expelling them first from the party. To expel members and candidate-members of the Central Committee from the party at that time was a difficult matter for Stalin. At the Tenth Congress of the party in 1921, at Lenin's suggestion a decision had been adopted and written into the active rules of the party to the effect that no member or candidate-member of the Central Committee

${ }^{5}$ Pravda, Aug. 22, 1936.

- Ibid., Aug. 23, 1936.

Ibid. 
could be expelled from the party without the agreement of two thirds of the members of a plenum of the Central Committee. ${ }^{8}$ Therefore Stalin had to call a plenum of the Central Committee in September 1936. He gave Ezhov (secretary of the Central Committee for matters pertaining to the NKVD, and chairman of the Control Committee of the Central Committee of the CPSU) the task of delivering a report against Bukharin and Rykov. However, the plenum refused to sanction Stalin's and Ezhov's demands. This didn't require any extraordinary heroism because the vote was by secret ballot. At this same plenum it became clear that not even the whole Politburo was on Stalin's side. I wrote: "Undoubtedly the most important fact which emerged from this assembly was the schism (predicted as certain in a few well-informed quarters of the Party, but obstinately denied by the Stalin group) in the Politburo itself. Of its twelve members [and candidate-members], fiveKossior, Postyshev, Chubar, Rudzutak, and Eikhe-supported Bukharin's contention that it was the NKVD and not the Party that was governing the country." " In his secret speech Khrushchev enumerated the same individuals as the leaders of the resistance against Stalin's and Ezhov's repressions: Kossior, Rudzutak, Chubar, Postyshev, Eikhe. ${ }^{10}$ This could hardly be accidental.

What happened after the plenum? I wrote that right after the plenum a note appeared on the pages of Pravda and Izvestiia stating that the investigation of the Bukharin-Rykov affair had been dropped, since no charge had been brought. Since I was writing at the time from memory, I was unable to indicate the exact date. Now we know that the note was published on September 10 in Pravda. It read: "In the USSR Procurator's Office.... The investigation has not established legal grounds for an arraignment of N. I. Bukharin and A. I. Rykov, in view of which further development of the case is terminated."

Armstrong calls this an "unexpected announcement." ${ }^{11}$ It is natural that it would seem unexpected to those who know party history only from reading Pravda, Soviet textbooks, and Khrushchev's speech at the Twentieth Congress. In reality, this was the result of a great and dramatic struggle at the top of the party against expansion of the purge. Specifically, it was the result of the September party plenum which ordered that the charges against the Bukharin group be dropped and that its members remain in the Central Committee. (The same plenum, however, directed that Piatakov be expelled from the Central Committee and the party and be brought to trial.)

Stalin, on the one hand, gave the impression that he had accepted the decision of the Central Committee, while, on the other, he continued to fight against it. The tactics which he used against the right wing between the September plenum of ${ }_{1936} 6$ and the February-March plenum of 1937 are extremely interesting. In order to eliminate the right wing, Stalin sallied forth under the banner of "liquidating Trotskyites." Khrushchev tells us that "at that time massive repressions took place under the slogan of battling with Trotskyites." ${ }^{12}$ In January 1937 Stalin and Ezhov conducted the trial of the so-called "Trotskyite Center," Piatakov and Radek. At this trial, just as at the Zinoviev trial, the defendants were forced to implicate Bukharin as their co-worker and ally. Radek was particularly helpful in this regard. The confrontation between Radek and Bukharin before the trial is described in The Reign

\footnotetext{
${ }^{8}$ See KPSS $v$ rezoliutsiiakh, Part I (Moscow, 1953), pp. 529-30.

- The Reign of Stalin, p. 46.

${ }^{10}$ Rech' Khrushcheva na zakrytom zasedanii XX s'ezda KPSS (Munich, 1956), pp. 20-24.

1 Politics of Totalitarianism, p. 51.

${ }^{12}$ Rech' Khrushcheva, p. 19.
} 
of Stalin. ${ }^{13}$ In this way Stalin was able to demonstrate to the majority of the Central Committee the mistake that they had made in refusing to exclude Bukharin from the Central Committee. Having demonstrated this error, Stalin convened a new plenum of the Central Committee in February-March 1937. However, even at this time Stalin was not certain of his victory; therefore he did not rely on Ezhov's report alone, but he himself made the main report on the "Bukharinites." Stalin's uncertainty of the outcome of this plenum is indicated in the subtle title of the reports that were given: "Concerning Inadequacies in Party Work, and the Task of Liquidating Trotskyites and Other Double-dealers." The "other double-dealers" were, of course, Bukharinites, but they were not directly attacked until the plenum itself, to prevent them from organizing an effective defense as they had done the previous September. In the title of Ezhov's report, too, there was no word concerning "Bukharinites," only Trotskyites. Unfortunately, it is still impossible to establish exactly how Stalin managed to expel Bukharin and Rykov from the party at this plenum, but one thing was known at that time, and Khrushchev confirmed it once again in his secret speech: Many of the members even of this plenum did not believe Stalin's assertion that the "other double-dealers" (Bukharinites) were connected with Trotskyite "anti-Soviet organizations." Khrushchev writes: "At the February-March plenum of the Central Committee in 1937 many members [emphasis added] seriously doubted the correctness of the adopted program in regard to mass repressions under the pretext of the struggle with 'double-dealers.' " ${ }^{14} \mathrm{Khru}$ shchev quoted excerpts from the speech of Postyshev, secretary of the Central Committee and candidate-member of the Politburo, in which Postyshev spoke out against Stalin and Ezhov. Refuting the accusations of Stalin and Ezhov that certain friends of Bukharin, for example, Karpov, were connected with Trotskyites, Postyshev said: "I don't believe it ... I can't imagine how it was possible to go with the party through those terrible years and then in 1934 go over to the Trotskyites. That is strange." 15

The necessity of eliminating the Bukharinites was the basis for Stalin's famous theory of the "sharpening of the class struggle during the period of building socialism" and further led to his stressing the point that the NKVD, as he had already pointed out, was four years behind in the pursuit of this task. His conclusion was that it was necessary to reinforce the struggle against class enemies and their ideologists. However, this conclusion wasn't accepted voluntarily at the February-March plenum but was forced on the plenum by Stalin and Ezhov. Here is the extremely valuable testimony of Khrushchev himself: "It must be noted that this formulation was also thrust on the February-March plenum of the Central Committee of the All-Union Communist Party (Bolsheviks) in 1937." 16

The members of the Central Committee, having returned to their homes, were arrested one by one until, by 1939,70 percent of the members who had voted against Stalin had been shot. As was to be expected from Stalin, those who were arrested were accused of having created, starting in 1935, a "reserve network of Bukharinites." ${ }^{27}$ This was already after Bukharin's trial (March 1938), but not even Ezhov was able to cope with such a task. According to Khrushchev, although the NKVD broke their ribs, they would not stick with their confessions when they ap-

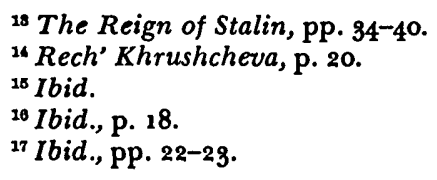


peared in court. Therefore they were shot individually, or shot without benefit of any legal proceedings. Thus the task had finally to be completed by Beria.

The removal of Yagoda and the telegram sent by Stalin and Zhdanov on September 25, 1936, concerning the appointment of Ezhov as Yagoda's successor indicate that not only did the Central Committee oppose Stalin's actions against Bukharin but even the NKVD was unable or unwilling to support Stalin's elimination of Bukharin. We must recognize that the notice concerning the dropping of the charges against Bukharin and Rykov, although formally issued in the name of the Procurator, must certainly have originated with the NKVD.

Since my critics fail to clarify the reasons for Stalin's elimination of the majority of the members of the Central Committee, let us turn again to the words of Khrushchev for an explanation of why Stalin liquidated zo percent of the members of the Central Committee who had never before taken any part in opposition to either Lenin or Stalin and who, furthermore, had been members of the Bolshevik party even before the Revolution. Khrushchev himself poses this question and gives an answer that is unique in the annals of crime. Here is his answer: "We have reexamined the cases of and rehabilitated Kossior, Rudzutak, Postyshev, Kosarev, and others. For what reason were they arrested and sentenced to be shot? The reexamined material indicates that there was no reason for this." ${ }^{18}$ It is, of course, unthinkable that Stalin executed 70 percent of the Central Committee without reason. I gave the reason in my book: A revolt was brewing against Stalin's use of the NKVD. (In speaking of the NKVD, we are not simply talking about the Lubianka, but about Stalin's whole network of secret police which he placed not only over the party but over the ordinary NKVD itself.) Armstrong says, and Slusser repeats, "If we accept as valid Khrushchev's remarks in his secret speech to the Twentieth Party Congress, this version is scarcely tenable." The essence of the matter is the fact that when we broaden the discussion of Stalin's personal crimes to include the crimes committed by Stalin together with the other members of the party apparat who helped Stalin (including Khrushchev), then it is not possible to expect that Khrushchev has told the entire story. For example, in my book I describe in detail how Khrushchev, together with Molotov and Ezhov, went to Kiev to liquidate Kossior and the other leaders of the Ukrainian Central Committee. ${ }^{10}$ This rendition was confirmed by Mosa Pijade, a member of the Politburo of the Yugoslav Communist Party ${ }^{20}$ (although the exact date of Kossior's arrest was not given).

It is interesting to note what sort of evolution took place concerning Khrushchev's presentation of the facts about Stalin's crimes. At the Twentieth Congress Khrushchev indicated that only three members of the Politburo were responsible for all the crimes, Stalin, Ezhov, and Beria. This was understandable because at the Twentieth Congress all the remaining members of Stalin's Politburo were present in important positions. At the Twenty-second Congress Khrushchev took a big step toward the truth but still did not tell the whole story: Khrushchev, Shelepin, and Serdiuk revealed that together with Stalin, Ezhov, and Beria the other members of Stalin's Politburo had taken part in Stalin's crimes-except for Khrushchev and Mikoyan. This too was understandable, because this congress was led by Khrushchev and Mikoyan, and the other members of the Stalin Politburo had, in 1957, been declared members of an "anti-party group" (Molotov, Kaganovich, Voroshilov, Malenkov).

We must remember that Khrushchev and his present heirs in the Kremlin unmasked

${ }^{18}$ Ibid., p. 26.

${ }^{10}$ The Reign of Stalin, p. 69.

${ }^{20}$ Dedijer, Tito Speaks (London, 1953), p. 102. 
Stalin not in search of historical truth but on grounds of political expediency. Therefore Khrushchev and his disciples consciously voiced a little truth about Stalin and silenced the greater truth about the party-that is, about themselves. Khrushchev's main thesis is the following: Stalin, operating through Ezhov and Beria, created lawlessness and acted in a non-Leninist fashion. But the party apparatus (obkomy, kraikomy, and republican central committees), operating on the basis of party regulations, and in spite of Stalin, Beria, and Ezhov, acted correctly and according to Lenin's doctrines. Therefore Khrushchev, speaking of Stalin's crimes at the center, said nothing about the party's crimes in the provinces. Why? The answer to this question was given five years before Khrushchev's speech in my book, The Reign of Stalin. I wrote that in the provinces the party, working with the NKVD, arrested five million "enemies of the people." To judge these "enemies of the people," special troikas composed of three members were created. The members were the chief of the local NKVD, the local procurator, and the secretary of the regional committee of the party. ${ }^{21}$ These troikas had the right to sentence the accused in absentia to two types of punishment: ten years' imprisonment or ten years' imprisonment "without correspondence rights." Imprisonment "without correspondence rights" was an NKVD euphemism for execution. Therefore we may say that the main responsibility for the physical destruction of the mass of people in the provinces must fall on the shoulders of the party apparatus; in other words, on the shoulders of the men who were then secretaries and members of obkomy, kraikomy, and republican central committees and who comprise the majority of the present Central Committee. Neither Khrushchev nor these other members of the Soviet leadership nor the party press has ever said a word about the existence of these troikas. Are we to think that they never existed because Khrushchev said nothing about them? In fact these troikas have been ignored not only by the Kremlin but by Armstrong as well, in his book The Politics of Totalitarianism, which Slusser has chosen to call "most detailed and reliable."

Professor Seton-Watson has written that my account of the plenum based on my memory of these events cannot be accepted without substantiation. However, he adds in the same place, "But it is not improbable and fits the facts that are known." ${ }^{22}$ In general, Professor Seton-Watson evaluates my book as one of the five "most useful" written by former Soviet citizens about the Ezhoushchina."

Professor Schapiro has written:

Thus, some tentative, if belated, opposition of nearly three-quarters of the Central Committee members and candidates to Stalin's policy of mass repression is, at any rate, not excluded. There is perhaps some doubt about the date when it was first voiced. An account by a former highly placed Party member, published in 1951, places the revolt of the Central Committee in the autumn of 1936. See A. Ouralov, Staline au Pouvoir, Paris, 1951, pp. $34^{-4} 4^{1.94}$

Professor Tucker considers still unanswered the question whether the September gathering was a full plenum or simply a meeting of several members. ${ }^{25}$

Doubts such as these concerning the details of my description are of course fully understandable. However, the facts which have been outlined previously seem to me

The Reign of Stalin, p. 137.

${ }^{2}$ From Lenin to Khrushchev (New York, 1960), p. 167.

2 Ibid., p. 415 .

${ }^{24}$ Leonard Schapiro, The Communist Party of the Soviet Union (New York, 1959), Pp. 414-15.

The Great Purge Trial (New York, 1965), p. xx. 
clearly to indicate that there existed an organized and very effective resistance to Stalin's actions from the majority of the Central Committee. The first result was the "unexpected" (for Armstrong) "announcement" of September 10, and subsequently the execution of 70 percent of the members of the Central Committee.

In conclusion, I would like to invite the attention of Messrs. Armstrong and Slusser to the following: Former United States ambassador to Moscow George F. Kennan, who served in Moscow during the period 1935-37, writes in his well-known work Russia and the West under Lenin and Stalin:

During Stalin's absence, at the beginning of September, there took place a plenary session of the Central Committee at which, once again, Stalin's will appears to have been defied by his associates. Bukharin was evidently supported; the investigation directed against him was, in any case, temporarily halted. Yagoda, the head of the secret police, who had once been close to Bukharin, appears to have come out on this issue against Stalin. ${ }^{20}$

Kennan also mentions the plenum again (on page 309) in connection with the sudden decision to intervene in Spain. What do my critics have to say about this?

Since my writings are primarily memoirs rather than scholarly research, they may, of course, contain errors of detail, but the fundamental facts and conclusions have been validated by events.

\section{Letter to the Editors}

\section{JOHN A. ARMSTRONG}

When you kindly sent me a copy of Mr. Abdurakhman Avtorkhanov's communication, "An Answer to My Critics," last February, I was rather surprised that he was attempting, at that late date, to refute the critical evaluation I had made in 1961 concerning his book, The Reign of Stalin. As I pointed out to you in my reply of February 27, my original evaluation had been made on the basis of my doubts concerning a number of factual assertions in the book, some of which Avtorkhanov had reaffirmed in his February 1967 communication. Since, however, you have understandably requested all concerned to limit their comments to the issue of the alleged "September 1936" plenum, I shall not discuss the other grounds I have for considering Avtorkhanov's factual account to be somewhat unreliable. In his revised communication, which you sent me at the end of July, Avtorkhanov recognizes that since his "writings are primarily memoirs rather than scholarly research, they may, of course, contain errors of detail." He stresses the importance of the validity of his conclusions; indeed, most of the revised communication is devoted to elucidating them. It would be interesting to examine these conclusions, but unfortunately Avtorkhanov's exchange of communication has proceeded at a different tempo from mine, and I now find that my imminent departure for an extended stay in Europe precludes my giving his revised message the attention it deserves. Consequently, I must confine my remarks to indicating as briefly as possible why I consider his assertion that there was a "September 1936" plenum to be unfounded. Regardless of whether the general interpretation he builds around this assertion is valid or not, the existence or nonexistence of a Central Committee plenum in such a crucial month is too important a historiographical question to be left unanalyzed. I am

${ }^{80}$ Russia and the West under Lenin and Stalin (Boston and Toronto, 1960), p. 307. 